\title{
Efektivitas Penggunaan LKS Problem Based Learning (PBL) Materi Aritmatika Ditinjau dari Kemampuan Berpikir Kreatif Matematika
}

\author{
Ersam Mahendrawan ${ }^{1}$, Ihat Solihat ${ }^{2}$, Maghfiroh Yanuarti ${ }^{3}$ \\ ${ }^{1,2}$ Program Studi Teknik Mesin, Fakultas Teknik, Universitas Pamulang \\ ${ }^{3}$ Program Studi Manajeman, Fakultas Ekonomi dan Bisnis, Universitas Pamulang \\ Jl.Surya Kencana No.1 Pamulang Barat, Pamulang, Tangerang Selatan, \\ dosen01329@unpam.ac.id
}

\begin{abstract}
Creative thinking ability is one of the cognitive aspects that students must have. Creative thinking ability are needed when a person faces an unusual problem or challenge. Currently, various learning approaches have been developed that can be used to create ideal learning conditions in order achieve learning objectives, including to improve students' mathematical creative thinking ability. One of strategy that can be uses was learning with worksheet based on Problem Based Learning (PBL) approach. The purpose of this study was to describe the effectiveness of PBL worksheets approach in terms of mathematical creative thinking abilities. This research was quasi-experimental research. The control class uses a conventional approach. Subjects of the research were students of SMP Darussalam Islamic Boarding School, Wonosobo. The research was carried out in March 2021. The instrument used in this study was a test instrument. The data analysis used were descriptive and inferential analysis. The results showed that Problem Based Learning (PBL) worksheets approach was more effective to improve mathematical creative thinking ability than conventional approaches.
\end{abstract}

Keywords: creative thingking, effectiveness, worksheet, Problem Based Learning

\begin{abstract}
Abstrak
Kemampuan berpikir kreatif menjadi salah satu aspek kognitif yang harus dimiliki siswa. Kemampuan bepikir kreatif dibutuhkan ketika seseorang menghadapi masalah atau tantangan yang tidak biasa. Saat ini telah banyak berkembang berbagai pendekatan pembelajaran yang dapat digunakan untuk menciptakan kondisi belajar yang ideal dalam rangka mencapai tujuan pembelajaran, termasuk untuk meningkatkan kemampuan berpikir kreatif matematis siswa. Salah satu strategi yaitu menggunakan LKS Problem Based Learning (PBL). Tujuan penelitian ini adalah untuk mendeskripsikan keefektifan LKS PBL ditinjau dari kemampuan berpikir kreatif matematis. Penelitian ini merupakan penelitian eksperimen semu. Kelas kontrol menggunakan pendekatan konvensional. Subjek penelitian yaitu siswa SMP Darussalam Islamic Boarding School, Wonosobo. Penelitian dilaksanakan pada Maret 2021. Instrumen yang digunakan dalam penelitian ini yaitu instrumen tes. Analisis data yang digunakan yaitu analisis deskriptif dan inferensial. Hasil penelitian menunjukkan bahwa penggunaan LKS Problem Based Learning (PBL) lebih efektif ditinjau dari kemampuan berpikir kreatif matematis dibandingkan dengan pendekatan konvensional.
\end{abstract}

Kata kunci: berpikir kreatif, keefektifan, LKS, matematika, Problem Based Learning

Copyright (c) 2022 Ersam Mahendrawan, Ihat Solihat, Maghfiroh Yanuarti

$\triangle$ Corresponding author: Ersam Mahendrawan

Email Address: dosen01329@unpam.ac.id (Jl.Surya Kencana No.1 Pamulang Barat, Pamulang, Tansel)

Received 17 November 2021, Accepted 06 January 2022, Published 17 Januari 2022

\section{PENDAHULUAN}

Pelajaran matematika menjadi pelajaran wajib bagi siswa dijenjang sekolah dasar hingga menengah bahkan di perguruan tinggi. Hal ini dikarenakan matematika merupakan ilmu pengetahuan yang memberikan kontribusi luar biasa bagi perkembangan ilmu pengetahuan dan teknologi. Berbagai kemampuan berpikir dilatih melalui pelajaran matematika, salah satunya adalah kemampuan berpikir kreatif. Kemampuan berpikir kreatif diperlukan ketika seseorang menghadapi suatu masalah ataupun tantangan yang tidak biasa. Berpikir kreatif melibatkan merupakan kemampuan untuk memperoleh ide baru dan asli yang menjadi sesuatu yang tidak biasa (McGredor, 2007). Berpikir kreatif adalah salah satu jenis berpikir yang sangat menarik dimana terkait dengan keterampilan kognitif dan 
kemampuan menemukan solusi baru untuk suatu masalah (Arends \& Kilcher, 2010).

Ciri berpikir kreatif adalah hasil yang orisinil (asli) dan cara-cara baru yang tidak diperkirakan sebelumnya (Crow \& Crow, 1977). Berpikir kreatif erat kaitannya dengan ide-ide untuk menemukan solusi dari suatu masalah. Sehingga berpikir kreatif dalam matematika erat kaitannya dengan proses untuk memecahkan masalah. Guilford (Lefrancois, 2000) menyatakan bahwa aspek berpikir kreatif meliputi kelancaram, keluwesan dan keaslian atau originalitas. Kreativitas erat kaitannya dengan berpikir divergen, yaitu berpikir untuk memperoleh ide-ide yang baru dan asli. Kreativitas sangat penting dimiliki siswa khususnya dalam proses pemecahan masalah yang tidak biasa. Karena kreativitas sangat berhubungan erat dengan proses berpikir maka kreativitas dalam aspek kognitif sering disebut dengan berpikir kreatif.

Berpikir kreatif yang melibatkan berpikir divergen, dijelaskan oleh Schlichter (Eragamreddy, 2013) yang menyatakan makna dari berpikir divergen meliputi kelancaran, keluwesan dan keaslian dan elaborasi. Hal ini selaras dengan pendapat Mahmudi (2010) yang menyatakan bahwa aspek berpikir kreatif matematika adalalah kelancaran, keluwesan, kebaruan dan keterincian Kelancaran adalah proses berpikir untuk memunculkan banyak ide. Keluwesan adalah berpikir dengan mampu menampilkan berbagai sudut pandang yang berbeda. Keaslian merupakan kemampuan berpikir untuk memunculkan ide baru yang tidak biasa. Sedangkan elaborasi adalah kemampuan berpikir dengan menggunkan cara-cara yang rinci atau detail. Setiap orang akan mempunyai kemampuan berpikir kreatif dengan tingkatan yang berbeda beda. Kemampuan tersebutpun bisa dikembangkan. Hanya saja kemampuan mereka tidak sama dan kemampuan tersebut bisa dikembangkan. Tingkatan kemampuan berpikir kreatif dibagi menjadi lima dari yang paling rendah sampai tertinggi (Siswono, 2010). Untuk meningkatkan kemampuan berpikir kreatif dilakukan berbagai cara salah satunya dengan aktifitas pemecahan masalah yang dapat melatih sekaligus mengembangkan kemampuan berpikir kreatif.

Ditingkat sekolah kemampuan berpikir kreatif dalam dilatih dalam pembelajaran matematika melalui pemberian soal-soal yang sesuai. Secara umum meningkatkan kemampuan berpikir kreatif dapat dilakukan melalui pemecahan masalah (problem solving), termasuk didalamnya adalah pemecahan masalah pada soal-soal terbuka. Masalah matematika terbuka dapat menjadi dasar dalam mengembangkan kemampuan berpikir kreatif matematika siswa. Soal atau masalah terbuka atau lebih sering sebut open ended problem adalah soal yang memiliki beragam solusi atau strategi untuk menyelesaikannya (Mahmudi, 2010).

Untuk mengetahui apakah suatu metode atau cara tertentu efektif dalam meningkatkan kemampuan berpikir kreatif, maka perlu dilakukan tes berpikir kreatif. Tes yang bertujuan untuk mengetahui atau mengukur kemampuan berpikir kreatif dilakukan dengan soal-soal atau masalah terbuka. Hal ini sesuai dengan yang dikemukan Mahmudi (2010) bahwa salah satu cara mengukur kemampuan berpikir kreatif adalah dengan soal terbuka, yaitu soal yang memiliki beragam solusi atau strategi penyelesaian. Hasil pekerjaan siswa dalam proses pemecahan masalah dianalisis untuk 
mengetahui level atau tingkatan kemampuan berpikir kreatif siswa.

Berdasarkan uraian di atas seharusnya seorang siswa harus mempunyai kemampuan berpikir kreatif yang tinggi. Namun faktanya, ditingkat SMP masih ditemukan fakta bahwa siswa kesulitan dalam mengerjakan soal-soal terbuka. Hal ini mengindikasikan bahwa kemampuan berpikir kreatif siswa masih perlu ditingkatkan. Upaya untuk meningkatkan kemampuan berpikir kreatif siswa dapat dilakukan dengan memperbaiki proses pembelajaran matematika yang ada di sekolah. Salah satunya dengan meningkatkan kualitas bahan belajar yaitu LKS. Lembar Kerja Siswa (LKS) atau student work sheet adalah bahan ajar yang dikemas sedemikian rupa, sehingga siswa dapat mempelajari materi tertentu (Prasetyawan \& Gunawan, 2020). Selain dapat berperan sebagai panduan siswa, LKS dapat ditujukan untuk tujuan khusus, salah satunya memfasilitasi siswa mengembangkan kemampuan berpikir kreatifnya. LKS yang ideal tidak hanya berisi soal-soal akan tetapi berisi langkah-langkah kegiatan yang menuntun siswa dalam melakukan pemecahan masalah (Prasetyawan \& Gunawan, 2020). LKS tidak hanya berisi soal-soal yang harus dikerjakan siswa, akan tetapi berisi kegiatan yang bermakna untuk dilakukan siswa dalam mengkonstruk pengetahuannya (Masitoh \& Hartono, 2017).

Terkait dengan upaya meningkatkan kemampuan berpikir kreatif alternatif pendekatan pembelajaran yang dapat digunakan adalah Problem Based Learning (PBL) (Masitoh, 2019). Pada pembelajaran dengan pendekatan PBL siswa diajak untuks mempelajari materi pelajaran sambil memecahkan suatu masalah (Jonassen, 2011). Aktivitas pemecahan masalah yang dilakukan siswa dalam kelas PBL akan terus melatih kempuan pemecahan masalahnya (Masitoh, 2019). Torp \& Sage (2002) mengemukakan bahwa PBL adalah pendekatan pembelajaran yang membantu proses belajar melalui investigasi. Inverstigasi merupakan kegiatan penyelidikan dalam rangka menyelesaikan masalah.

Proses investigasi dapat dilakukan baik secara individu maupun berkelompok (Arends \& Kilcher, 2010). Proses investigasi merupakan kunci dalam upaya memfasilitasi siswa mengembangkan kemampuan berpikir kreatifnya. Dalam proses ini siswa dilibatkan secara aktif dalam mengidentifikasi suatu masalah, memahami masalah dan memecahkan masalah tersebut, sampai akhirnya siswa mendapatkan pengetahuan baru dari proses penyelesaian masalah tersebut. Proses investigasi menuntut siswa untuk berfikir kritis, kreatif dan memonitor pemahaman mereka (Sungur \& Tekkaya, 2006). Pendapat ini menunjukkan bahwa pembelajaran dengan PBL memberikan fasilitas belajar bagi siswa untuk mengembangkan kemampuan berfikir kritis dan kreatif. Hal ini juga dikemukakan oleh Chakrabarty \& Muhamed (2013) serta Uden \& Beaumont (2006) bahwa PBL memberi kesempatan memberikan kesempatan untuk siswa melatih kemampuan berpikir kritis dan kreatif mereka. Masalah adalah titik awal dalam pembelajaran dengan pendekatan PBL. Masalah tersebut harus dipecahkan oleh siswa sebagai sarana mengkonstruk pengetahuan dan melatih kemampuan berpikir kreatifnya. Kelas PBL yang tepat adalah pembelajaran yang mengaharuskan 
Efektivitas Penggunaan LKS Problem Based Learning (PBL) Materi Aritmatika Ditinjau dari Kemampuan Berpikir Kreatif Matematika, Ersam Mahendrawan ${ }^{1}$, Ihat Solihat ${ }^{2}$, Maghfiroh Yanuarti

siswa menggunakan kemampuan berpikir kreatifnya (Bilgin, Şenocak, \& Sözbilir, 2009). Dengan demikian PBL dapat mengilustrasikan sesuatu yang berpotensi untuk meningkatkan berpikir kreatif siswa.

Ciri khusus PBL adalah masalah sebagai dasar belajar siswa. Akan tetapi beberapa akhir mengungkapkan langkah-langkah dalam melaksanakan pembelajaran di kelas PBL. PBL dapat dimulai dari penyajian masalah dan mengorganisasi siswa untuk belajar dalam kelompok-kelompok, melakukan peyelidikan sampai mempresentasikan hasilnya (Arends \& Kilcher, 2010). Hal ini sejalan denga pendapat Arends (2008) yang mengemukakan langkah-langkah pembelajaran dengan PBL diawali dengan orientasi masalah, mengorganisasi siswa untuk meneliti, membantu investigasi mandiri dan kelompok, mengembangkan dan mempresentasikan hasil serta terakhir mengevaluasi proses mengatasi masalah. Secara umum, pembelajaran dengan pendekatan PBL dapat dilakukan dengan lima langkah utama, yaitu menyiapkan siswa, orientasi masalah, investigasi, presentasi atau mengkomunikasikan dan evaluasi. Pada langkah menyiapkan siswa, guru mengorganisasi siswa untuk belajar. Pada langkah kedua orientasi masalah, guru dapat mengajukan fenomena atau masalah yang menjadi dasar bagi siswa untuk belajar.

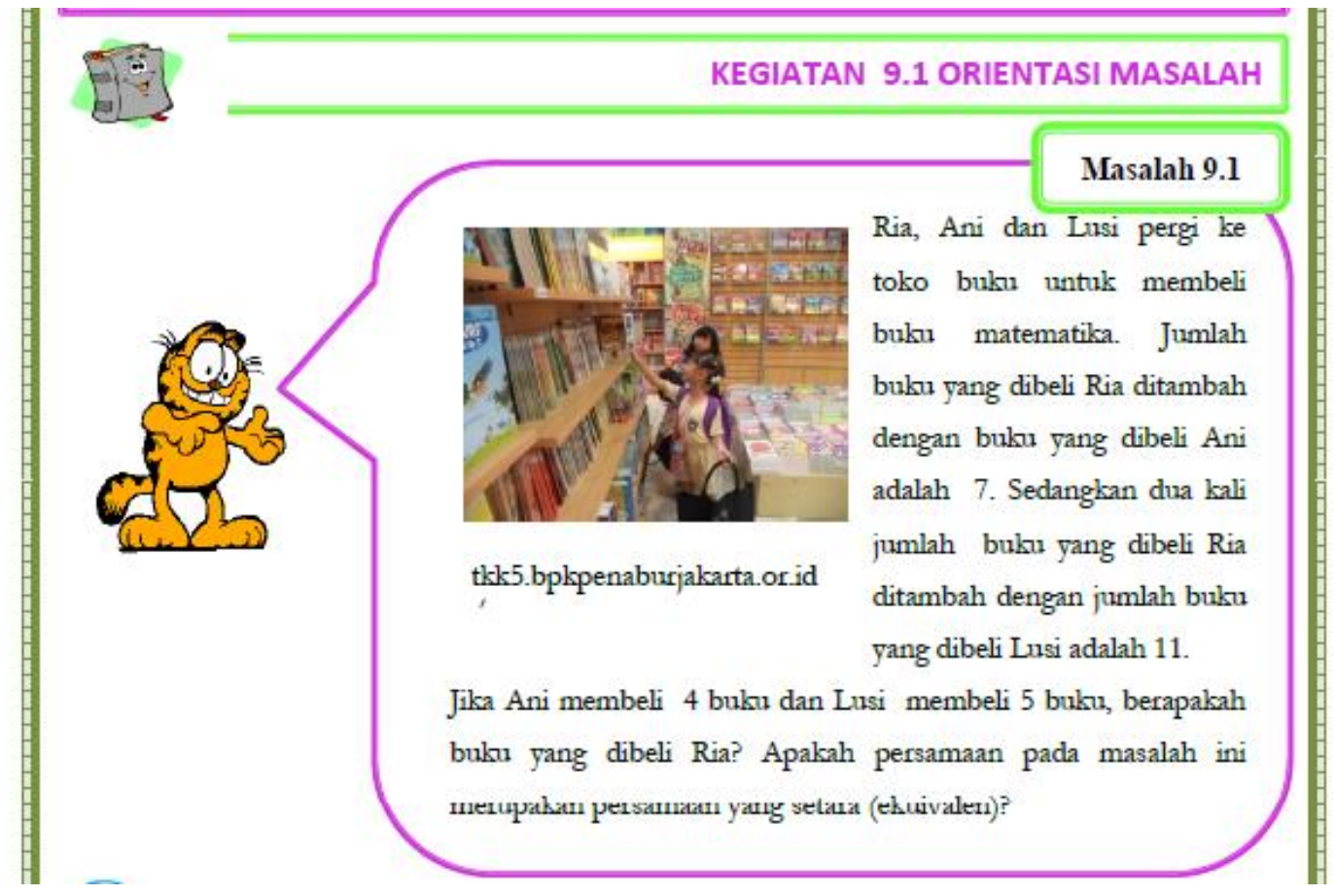

Gambar 1. Orientasi Masalah

Selanjutnya siswa mendefinisikan masalah utama yang akan mereka pecahkan, dan apa yang dibutuhkan untuk memecahkan masalah tersebut. Selanjutnya pada langkah investigasi, siswa melakukan penyelidikan, berdiskusi mencari ide-ide untuk memecahkan atau menyelesaikan masalah. 


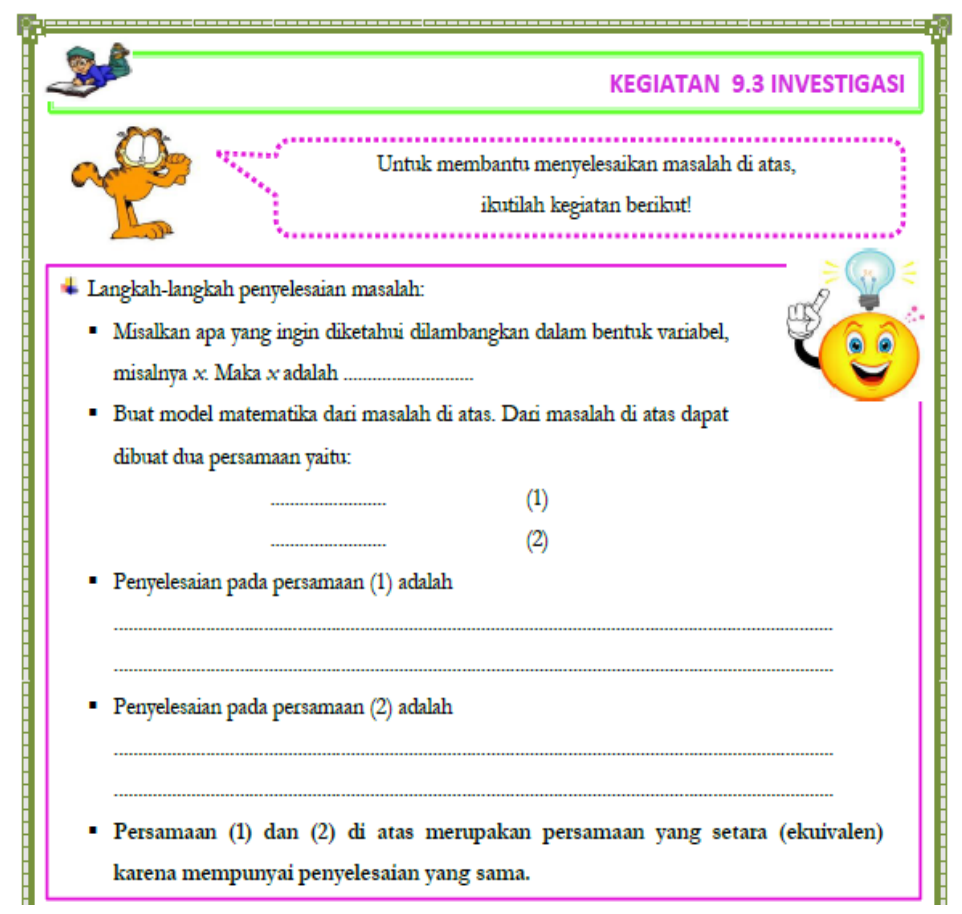

Gambar 2. Investigasi

Setelah mendapatkan solusi dari masalah, siswa melihat kembali dan mengoreksi kembali hasil pemecahan masalah yang dilakukan, untuk memastikan bahwa proses dan hasil yang diperoleh sudah tepat atau tidak salah. Langkah selanjutnya adalah presentasi.

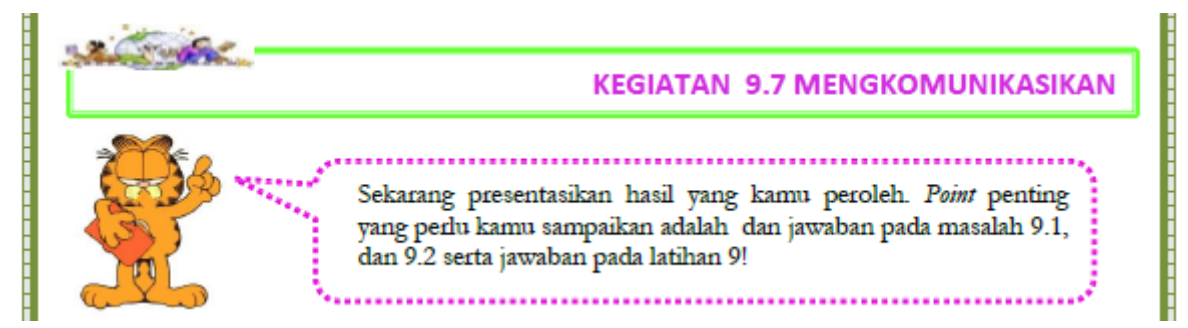

Gambar 3. Presentasi

Tahap terakhir adalah evaluasi dimana siswa melakukan refleksi atau evaluasi terhadap penyelidikan mereka dan proses-proses yang mereka gunakan dalam memecahkan masalah.

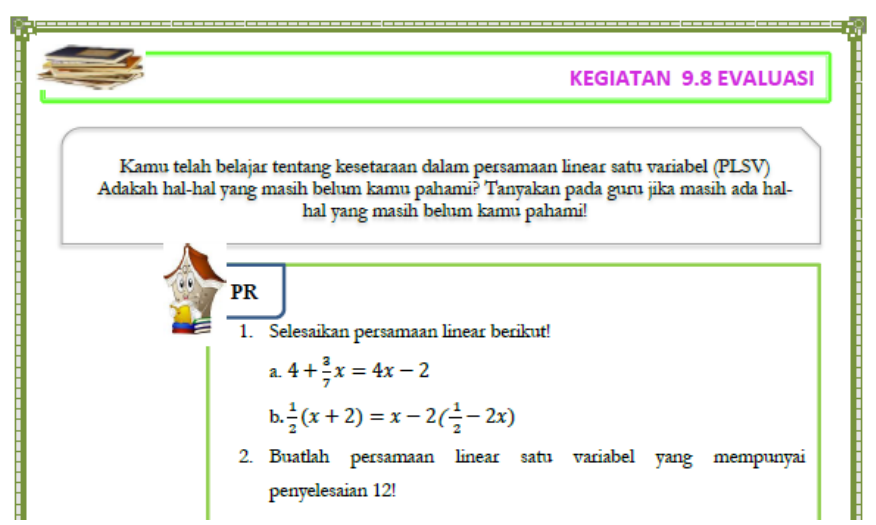

Gambar 4. Evaluasi 
Dengan potensi yang dimiliki pendektan PBL untuk memfasilitasi siswa mengembangkan kemampuan berpikir kreatifnya, peneliti bermaksud untuk mengetahui keefektifan LKS Problem Based Learning ditinjau dari kemampuan bepikir kreatif matematis siswa. Materi yang diangkat yaitu aritmatika. Kelas konvensional akan dipilih sebagai kelas kontrolnya.

\section{METODE}

Penelitian ini termasuk kedalam jenis penelitian quasi eksperimen. Penelitian quasi eksperiment didasarkan pada asumsi bahwa kelas-kelas yang dijadikan eksperimen adalah setara. Dalam penelitian eksperimen hipotesis menyangkut hubungan kasual (sebab-akibat) akan diuji secara benar (Gay, 1981). Dalam hal ini akan diterapkan LKS Problem Based Learning dan dibandingkan dengan pembelajaran secara konvensional untuk melihat akibat yang bakan ditimbulkan khususnya pada variabel terikat yang akan diteliti, yaitu kemampuan berpikir kreatif matematis. Metode pengumpualan data yang digunakan dalam penelitian ini adalah tes. Secara khusus, data tentang kemampuan berpikir kreatif matematis dilakukan dengan menggunakan tes tertulis. Tes dilakukan sebelum treatment untuk mengetahui kemampuan berpikir matematis awal siswa sebelum mendapatkan treatment. Selanjutnya dilakukan tes kembali yaitu tes setelah pemberian treatment untuk mengetahui kemampuan berpikir matematis siswa setelah mendapatkan treatment. Analisis data yang digunakan dalam penelitian ini adalah analisis deskriptif dan analisis inferensial dengan perhitungan menggunakan bantuan program SPSS.

\section{Analisis Deskriptif}

Data penelitian yang dianalisis adalah data pretest dan posttest pada aspek kemampuan berpikir kreatif. Data yang disajikan berupa rata-rata, standar deviasi, nilai tertinggi yang dicapai, nilai terendah yang dicapai, nilai maksimum yang mungkin, dan nilai minimum. Data tentang kemampuan berpikir kreatif diperoleh melalui pengukuran dengan instrumen tes. Untuk tes prestasi belajar Instrumen yang digunakan adalah tes uraian. Selanjutnya data tentang kemampuan berpikir kreatif diinterpretasikan kedalam kriteria-kriteria yang telah ditetapkan. Untuk menentukan kriteria digunakan klasifikasi berdasarkan rata-rata ideal (Mi) dan standar deviasi ideal (Si). Konversi skor kemampuan berpikir kreatif merujuk pada Tabel 1 berikut.

Tabel 1 Konversi Skor Kemampuan Berpikir Kreatif (Kuantitatif ke Kualitatif Skala lima)

\begin{tabular}{|c|c|}
\hline Skor Interval & Kriteria \\
\hline $\mathrm{X}>75$ & Sangat Baik \\
\hline $58<\mathrm{X} \leq 75$ & Baik \\
\hline $42<\mathrm{X} \leq 58$ & Cukup Baik \\
\hline $25<\mathrm{X} \leq 42$ & Kurang Baik \\
\hline $\mathrm{X} \leq 25$ & Sangat Kurang Baik \\
\hline
\end{tabular}




\section{Analisis Inferensial}

Teknik analisis data yang digunakan adalah analis univariat dengan sebelumnya dilakukan uji prasarat yaitu uji normalitas dan uji homogenitas. Analisis dilakukan dengan bantuan program SPSS. Pendekatan pembelajaran dikatakan efektif jika rata-rata nilai siswa lebih dari atau sama dengan 70 . Uji yang digunakan adalah one sample t-test untuk melihat keefektifan masing-masing pendekatan (Nuryadi et al, 2017). Uji one sample t-test dapat dilakukan jika data berasal dari populasi berdistribusi normal Jika kedua pendekatan baik PBL maupun konvensioanl efektif, maka dilalukan uji perbandingan keefektifan pendekatan pembelajaran dengan menggunakan uji ANOVA (Analysis of Variance). Jika hasil uji univariat terdapat perbedaan keefektifan antara kedua pendekatan pembelajaran, maka dilakukan uji lanjut (post hoc) untuk melihat pendekatan pembelajaran mana yang lebih efektif. Namun, jika hasil uji multivariat menunjukkan tidak terdapat perbedaan keefektifan antara kedua pendekatan pembelajaran maka uji lanjut tidak dilakukan.

\section{HASIL DAN DISKUSI}

\section{Data Kemampuan Berpikir Kreatif}

Data dalam penelitian ini dibedakan menjadi dua yaitu data sebelum perlakuan dan data setelah diberi perlakuan. Data memuat pretest dan posttest kemampuan berpikir kreatif. Berikut merupakan deskripsi hasil tes kemampuan berpikir kreatif, baik yang mendapatkan perlakuan pendekatan PBL maupun pendekatan konvensional yang disajikan pada Tabel 2 berikut.

Tabel 2. Hasil Kemampuan Berpikir Kreatif

\begin{tabular}{|l|c|c|c|c|}
\hline \multirow{2}{*}{ Deskripsi } & \multicolumn{3}{|c|}{ Kelompok Eksperimen (PBL) } & Kelompok Kontrol (Konvensioal) \\
\cline { 2 - 5 } & Pretest & Posttest & Pretest & Posttest \\
\hline Rata-rata & 32.44 & 77.07 & 32.91 & 63.02 \\
\hline Standar Deviasi & 11.49 & 6.22 & 14.72 & 6.99 \\
\hline Nilai maksimum ideal & 100 & 100 & 100 & 100 \\
\hline Nilai minimum ideal & 0 & 0 & 0 & 0 \\
\hline Nilai maksimum & 57 & 90 & 67 & 77 \\
\hline Nilai minimum & 20 & 60 & 20 & 45 \\
\hline Ketuntasan (\%) & $0 \%$ & $92.10 \%$ & $0 \%$ & 76.31 \\
\hline
\end{tabular}

Berdasarkan Tabel 2 di atas, rata-rata nilai posttest kemampuan berpikir kreatif siswa lebih dari nilai rata-rata pretest baik dari kelas yang mendapatkan perlakuan menggunakan LKS PBL maupun menggunakan pendekatan konvensional. Nilai rata-rata kemampuan berpikir kreatif untuk kelas dengan LKS PBL meningkat dari pretest dengan nilai 32.44 menjadi 77.07 pada posttest, artinya terdapat peningkatan sebesar 44,63. Hasil ini menunjukkan bahwa rata-rata nilai siswa setelah diberi perlakuan telah mencapai kriteria minimum yang ditetapkan yaitu 70. Untuk kelas konvensional, nilai rata-rata kemampuan berpikir keatif siswa dari pretest dengan nilai 32.91 menjadi 63.02 pada posttest artinya meningkat 30.11. Berdasarkan persentase ketuntasan, sebelum diberikan perlakuan kedua kelas baik kelas dengan pendekatan PBL maupun konvensional tidak ada siswa yang tuntas atau 
Efektivitas Penggunaan LKS Problem Based Learning (PBL) Materi Aritmatika Ditinjau dari Kemampuan Berpikir Kreatif Matematika, Ersam Mahendrawan ${ }^{1}$, Ihat Solihat ${ }^{2}$, Maghfiroh Yanuarti

mencapai nilai 70. Kemudian setelah diberi perlakuan, persentase ketuntasan pada kelas dengan LKS PBL mencapai 92.10\% atau sebanyak 35 dari 38 siswa. Sementara kelas konvensional mencapai 65.78\% atau 25 dari 38 siswa. Distribusi frekuensi kemampuan berpikir kreatif siswa dapat dilihat pada Tabel 3 berikut.

Tabel 3. Distribusi Kemampuan Berpikir Kreatif

\begin{tabular}{|c|c|c|c|c|c|c|c|c|c|}
\hline \multirow{3}{*}{ Interval Skor } & \multirow{3}{*}{ Kriteria } & \multicolumn{4}{|c|}{$\begin{array}{c}\text { Kelompok Eksperimen } \\
\text { (PBL) }\end{array}$} & \multicolumn{4}{|c|}{$\begin{array}{c}\text { Kelompok Kontrol } \\
\text { (konvensional) }\end{array}$} \\
\hline & & \multicolumn{2}{|c|}{ Pretest } & \multicolumn{2}{|c|}{ Posttest } & \multicolumn{2}{|c|}{ Pretest } & \multicolumn{2}{|c|}{ Posttest } \\
\hline & & f & $\%$ & f & $\%$ & f & $\%$ & f & $\%$ \\
\hline$X>75$ & Sangat baik & 0 & $0 \%$ & 28 & $73.68 \%$ & 0 & $0 \%$ & 10 & $26.32 \%$ \\
\hline $58<X \leq 75$ & Baik & 0 & $0 \%$ & 10 & $26.32 \%$ & 4 & $10.53 \%$ & 23 & $60.52 \%$ \\
\hline $42<X \leq 58$ & Cukup baik & 8 & $21.05 \%$ & 0 & $0 \%$ & 7 & $18.42 \%$ & 5 & $13.16 \%$ \\
\hline $25<X \leq 42$ & Kurang baik & 8 & $21.05 \%$ & 0 & $0 \%$ & 1 & $2.63 \%$ & 0 & $0 \%$ \\
\hline$X \leq 25$ & $\begin{array}{l}\text { Sangat kurang } \\
\text { baik }\end{array}$ & 22 & $57.90 \%$ & 0 & $0 \%$ & 26 & $68.42 \%$ & 0 & $0 \%$ \\
\hline
\end{tabular}

Berdasarkan Tabel 3 di atas, pada kelas dengan LKS PBL terlihat bahwa sebelum pembelajaran kemampuan berpikir kreatif siswa mayoritas berada pada kategori sangat kurang baik, yaitu mencapai 22 siswa atau $57.90 \%$. Sebanyak 8 siswa atau $21.05 \%$ dengan kategori kurang baik dan 8 siswa atau $21.05 \%$ siswa mempunyai kemampuan berpikir kreatif pada kategori cukup baik. Pada awalnya tidak ada siswa yang mempunyai kemampuan berpikir kreatif baik maupun sangat baik. Namun setelah dilakukan pembelajaran dengan LKS PBL diperoleh kenaikan data nilai kemampuan berpikir kreatif siswa. Sebanyak 10 siswa atau 26.32\% mempunyai kemampuan berpikir kreatif dengan kategori baik dan sebanyak 28 siswa atau $73.68 \%$ dengan kategori sangat baik.

Kondisi awal yang sama terjadi pada kelas dengan pembelajaran konvensional. Pada kelas dengan pembelajaran konvensional terlihat bahwa sebelum pembelajaran kemampuan berpikir kreatif siswa mayoritas berada pada kategori sangat kurang baik, yaitu mencapai 26 siswa atau $68.42 \%$. Sebanyak 1 siswa atau $2.63 \%$ dengan kategori kurang baik, 7 siswa atau $18.42 \%$ siswa mempunyai kemampuan berpikir kreatif pada kategori cukup baik dan 4 siswa atau $10.53 \%$ mempunyai kemampuan berpikir kreatif baik. Pada awalnya tidak ada siswa yang mempunyai kemampuan berpikir kreatif sangat baik. Setelah dilakukan pembelajaran diperoleh kenaikan data nilai kemampuan berpikir kreatif siswa. Sebanyak 5 siswa atau $13.16 \%$ mempunyai kemampuan berpikir kreatif dengan kategori cukup baik, 23 siswa atau $60.52 \%$ pada kategori baik dan sebanyak 10 siswa atau $26.32 \%$ dengan kategori sangat baik.

\section{Hasil Uji Hipotesis}

Nilai perbandingan dengan uji Paired T Test baik pada kelas dengan LKS PBL dan konvensional menghasilkan output nilai sig. (2-tailed): 0.000. Artinya ada perbedaan antara sebelum dan sesudah perlakuan. Kedua kelas menunjukkan peningkatan nilai kemampuan berpikir kreatif diakhir pembelajaran. Hasil dari uji One Sample T Tes menunjukan output nilai sig. (2-tailed): 0.000 yang 
artinya terdapat perbedaan yang singnifikan antara kedua pendekatan. Pada uji lanjut diperoleh hasil bahwa pendekatan dengan LKS PBL lebih efektif dibandingkan dengan pembelajaran dengan pendekatan konvensional. Efektifnya pendekatan dengan LKS PBL ini telah dibuktikan pula dengan penelitian-penelitian sebelumnya, yaitu penelitian oleh Fadrik (2017) yang hasilnya menyebutkan bahwa PBL efektif dalam meningkatkan kemampuan berpikir kreatif siswa program studi Tadris Matematika UIN Mataram. Selain itu, hasil penelitian yang dilakukan oleh Aryani et al (2015) menunjukkan bahwa PBL efektif digunakan untuk meningkatkan kemampuan bepikir kreatif siswa program studi Pendidikan Biologi Universitas Sebelas Maret.

\section{KESIMPULAN}

Berdasarkan hasil analisis data dan pembahasan yang telah diuraikan sebelumnya, maka dapat disimpulkan bahwa baik pembelajaran dengan pendekatan konvensional dan dengan LKS Problem Based Learning (PBL) efektif ditinjau dari kemampuan berpikir kreatif matematis. Hasil perbandingan kedua pendekatan menunjukkan bahwa pendekatan dengan LKS PBL lebih efektif dibandingkan dengan pendekatan konvensional. Dari hasil ini disarankan bagi pengajar disekolah khususnya ditingkat Sekolah Menengah Pertama untuk dapat menerapkan pembelajaran dengan LKS PBL dalam pembelajaran matematika dikelas dalam rangka melatih dan meningkatkan kemampuan berpikir kreatif siswa.

\section{REFERENSI}

Arends, R. I., \& Kilcher, A. (2010). Learning to teach: belajar untuk mengajar. (Terjemahan Helly Prajitno Soetjipto \& Sri mulyani Soetjipto. New York: Taylor \& Francis Group.

Arends, R. I. (2008). Teaching for student learning: Becoming an accomplished teacher. New York: Taylor \& Francis Group.

Aryani, I., Masykuri, M., \& Maridi. (2015). Pengembangan Modul Problem Based Learning (PBL) Pada Materi Populasi Hewan Untuk Meningkatkan Kemampuan Berpikir Kreatif Mahasiswa Pendidikan Biologi Universitas Sebelas Maret. Jurnal Inkuiri, 4(3), 68-77.

Bilgin, I., Şenocak, E., \& Sözbilir, M. (2009). The effects of problem-based learning instruction on university students' performance of conceptual and quantitative problems in gas concepts. Eurasia Journal of Mathematics, Science and Technology Education, 5(2), 153-164. https://doi.org/10.12973/ejmste/75267

Chakrabarty, S., \& Muhamed, N. (2013). Problem based learning: Cultural diverse students' engagement, learning and contextualized problem solving in a mathematics class. Wcik EJournal of Integration Knowledge. Wcik E-Journal of Integration Knowledge, 38-49.

Crow, L. D., \& Crow, A. (1977). Psikologi pendidikan. (Terjemahan Drs. Z. Kasijan). New York: American Book Company.

Eragamreddy, N. (2013). Teaching creative thinking skills. International Journal of English Language \& Translation Studies. International Journal of English Language \& Translation Studies, 1(2), $124-145$. 
Fadrik, A., F. (2017). Efektivitas Problem Based Learning Terhadap Kemampuan Berpikir Kreatif Siswa Program Studi Tadris Matematika UIM Mataram. Jurnal Teori Dan Aplikasi Matematika, $1(1), 48-54$.

Gay, L. R. (1981). Education Research: Competencies for Analisis and Aplication. Columbus: Charles E. Merrill Publishing Company.

Jonassen, D. H. (2011). Learning to solve problem: A handbook for designing problem solving learning environments. New York: Routledge.

Lefrancois, G. R. (2000). Psychology for teaching. London: Wadsworth Thamson Learning.

Mahmudi, A. (2010). Mengukur Kemampuan Berpikir Kreatif Matematis.

Masitoh, L. F. (2019). the Effectiveness of Problem Based Learning (Pbl) Approach Viewed From the Students' Mathematical Creative Thinking Ability. JPMI (Jurnal Pendidikan Matematika Indonesia), 4(2), 47. https://doi.org/10.26737/jpmi.v4i2.699

Masitoh, L. F., \& Hartono, H. (2017). Pengembangan Perangkat Pembelajaran Matematika dengan Pendekatan PBL Berorientasi pada Kemampuan Berpikir Kreatif dan Self-Efficacy Developing Mathematics Instructional Materials Using PBL Approach Oriented to Creative Thinking Ability and Self-Efficacy. Jurnal Pendidikan Matematika, 12(2), 220-230.

McGredor, D. (2007). Developing thinking; developing learning: A guide to thinking skills in education. New: Open University Press.

Nuryadi et al. (2017). Dasar-Dasar Statistik Penelitian. Yogyakarta: Sibuku media.

Prasetyawan, E., \& Gunawan, H. I. (2020). Pengembangan LKS Matematika Saintifik SMP Kelas VIII Berbasis Multiple Intelligences Gardner. Jurnal Cendekia : Jurnal Pendidikan Matematika, 4(2), 914-925. https://doi.org/10.31004/cendekia.v4i2.329

Siswono, T. Y. E. (2010). Leveling students' creative thinking in solving and posing mathematical problem. Journal on Mathematics Education, 1(1), 17-40. https://doi.org/10.22342/jme.1.1.794.17-40

Sungur, S., \& Tekkaya, C. (2006). Effect of problem based learning and traditional instruction on selfregulated learning. The Journal of Educational Research, 99(5), 307-317.

Torp, L., \& Sage, S. (2002). Problem as possibilities: Problem based learning for K-16 education (2nd ed). Alexandria: ASCD.

Uden, L., \& Beaumont, C. (2006). Technology and problem based learning. Hershey, PA: Idea Group. 